\title{
Linkages between Dynamic Financial Inclusion and Institutions in ASEAN 8
}

\author{
Tunjung Sekar Laksmi Pandhit ${ }^{1)}$, Malik Cahyadin ${ }^{2)}$ \\ ${ }^{1} \mathrm{PT}$ Putra Alam Teknologi \\ email: sekarpandhit@gmail.com \\ ${ }^{2}$ Faculty of Economics and Business, University Sebelas Maret \\ Corresponding Author: malikcahyadin@gmail.com
}

Received: March 2020 | Revised: June 2020 | Accepted: July 2020

\begin{abstract}
Financial inclusion becomes a priority concern with governments in ASEAN countries such as reduce the lack of access for public to formal financial institutions. Moreover, there is an empirical gap of linkages between institutions and financial inclusion. Thus, the study aims to estimate the effect of institutions on dynamic financial inclusion. Three financial inclusion indicators are employed, namely: debit card ownership, credit card ownership, and domestic credit to GDP ratio. Institutional indicators consist of six indicators following world governance indicators. The research observations are about 88 consisting of cross-sections were eight of ASEAN countries and the time series was 2008-2018. Indeed, a dynamic panel data was employed. In general, the findings exhibit that FEM is the appropriate model under Hausman test. Specifically, debit card ownership and credit card ownership were determined by voice and accountability, and rule of law while domestic credit to GDP ratio was determined by some indicators of institutions such as voice and accountability, political stability, regulatory quality, and control of corruption. Hence, the policy implications were directed to improve the quality of institutions both country and ASEAN levels. The high quality of institutions will stimulate the acceleration and expansion of financial inclusion in ASEAN countries.
\end{abstract}

Keywords: Financial inclusion; institutions; dynamic panel data JEL classification: C23; E02; O17

How to Cite: Pandhit T. S. L., Chayadin M.. (2020). Linkages between Dynamic Financial inclusion and Institutions in ASEAN 8. Jurnal Ekonomi Pembangunan: Kajian Masalah Ekonomi dan Pembangunan, 20(2). 174-186. doi:https://doi.org/10.23917/jep.v21i2.11146

DOI: https://doi.org/10.23917/jep.v21i2.11146

\section{Introduction}

Financial inclusion is designed to solve systemic and institutional weaknesses in financial institutions and transactions. Arun \& Kamath (2015) have adopted the definition of financial inclusion by the Center for Financial Inclusion as a "state in which everyone who can use them has access to a full suite of quality financial services, provided at affordable prices, in a convenient manner, with respect and dignity". Some barriers of financial inclusion were identified by Akudugu (2013) such as rules and regulations of formal financial market operations. These obstacles slow down the development of financial inclusion in a country because of mismatch policies in financial inclusion penetration. Moreover, inappropriate rules and regulations can make the risk for the public, especially those in rural areas to enter the formal financial sector. For example, creditworthiness issues because most people who 
Jurnal Ekonomi Pembangunan: Kajian Masalah Ekonomi dan Pembangunan, 21 (2), 2020, 174-186

enter the formal financial sector should qualify according to the credit scheme (Akudugu, Egyir \& Akwasi, 2009).

Sarma (2016) has developed a measurement of financial inclusion in Asia using an index called the index of financial inclusion (IFI). IFI is calculated based on three dimensions, namely: banking penetration, banking services, and use of the banking system. Besides, the IFI will be worth 0 to 1 that the higher the value of IFI indicates the higher the financial inclusion. Some previous studies also utilizes financial inclusion index in various spectrum such as Anarfo, Abor \& Osei (2019) in Sub-Saharan Africa countries; Nkoa \& Song (2020) in 51 African countries; and Khan, Gu, Khan \& Oláh (2020) in 87 Emerging and Developing Economies.

Previous studies elaborate the linkage between financial inclusion and institutions in various ways. For example, financial inclusion for male- and female-headed household are quite different in India (Ghosh \& Vinod, 2017). Some factors can determine for female-headed household to access formal financial institutions such as education, wages, political and social factors. Financial inclusion can also be determined by quality of human development (Datta \& Singh, 2019). Human development consist of quality of education and health. Hence, the high quality of education and health will lead improving financial inclusion. Burlando \& Canidio (2017) found that poor households in Uganda do not able to provide credit to its members because of the value of saving is less than that of credit. It means that financial inclusion in poor households depend on their ability to meet saving and credit. Furthermore, the quality of financial institution in groups of poor households is quite low. Restricting individuals from entering the formal financial sector can drive them switch to the informal financial market. Christen and Pearce (2005) describe that household savings remain the main source of funding for several small scale production activities, small farmers, and microbusinesses because they consider that formal finance creates a high cost of a transaction.
Moreover, at the macro level, the significant implication of institutional quality on financial inclusion has been expressed by Nkoa \& Song (2020). Quality of institutions can be stimulated by high level of trust. Indeed, there is a significant impact of trust on financial inclusion (Xu, 2019).

Some empirical findings express significant contribution of institutions both micro- and macro-levels. In constrast, there is lacking to estimate the impact of institutions on dynamic financial indicators in ASEAN countries. Thus, this study concerns on the empirical gaps. There are eight ASEAN countries still facing low level of institutional quality, namely: Indonesia, Malaysia, Thailand, Cambodia, the Philippines, Vietnam, Lao PDR, and Myanmar.

ASEAN countries can accelerate financial inclusion by innovating in the development of financial infrastructure and improving quality of institutions. Loo (2019) argues that the availability of banking infrastructure, control of corruption and supervision of financial access to marginalized communities can be a strategic policy. Interestingly, Arun \& Kamath (2015) report some ASEAN countries under two stages of financial inclusion. The first stage is financial inclusion progression based on adoption-2012 shows that: (a) Indonesia and the Philippines were categoried as Early Days, (b) Malaysia was categoried as Transitioning, and (c) Singapore was categoried as Most Advanced. Meanwhile, the second stage is financial inclusion based on degree of payments usage-2012 exhibits that: (a) Indonesia was categoried as Early Days, (b) the Philippines and Malaysia were categoried as Transitioning, and (c) Singapore was categoried as Payments Ready. Hence, this study focuses on financial inclusion and institutions in ASEAN 8 contries.

The development of institutional indicators in ASEAN 8 indicates an increasing trend. However, during the study period, the quality of institutions is still weak (between -1 to 0). Figure 1 describes the level of six institutional indicators in ASEAN 8 during 2008-2018. Government effectiveness (GE) is an indicator of institutions which has the 
highest level compared to five other institutional indicators. In contrast, voice and accountability (VA) has the lowest level. It exhibits that the effectiveness of government policies and their implementation need to be improved. Likewise, transparency and accountability in the ASEAN countries is also still low.

In general, the higher value of institutional indicators expresses the higher quality of institutions. From this point, all economic agents will be stimulated to respond and increase financial transaction in order to improve financial inclusion in ASEAN countries. Specifically, financial inclusion is directed to create expanded access, the fairness of financial transactions, and economic efficiency. Thus, governments in the ASEAN region can conduct financial inclusion policies and strategies together, integrated, and mutually beneficial. This policy can also be directed to the support the ASEAN economic community (AEC) implementation.

This study provides an objective is estimating the impact of institutions indicators on dynamic financial inclusion in ASEAN 8 during 2008-2018. Three financial inclusion indicators are utilized, namely: debit card ownership, credit card ownership, and domestic credit to GDP ratio. These indicators are widely used by previous empirical studies. Meanwhile, six institutional indicators were selected based on world governance indicators published by the World Bank. Most of the previous empirical studies largely ignore the contribution of institutions on financial inclusion in ASEAN countries.

This study contributes to the existence of literature in several ways. First, the study exhibits the linkage of financial inclusion and institutions in selected ASEAN countries. Three indicators of financial inclusion and six indicators of institutions were utilized. The findings will express the significant contribution of institutions on financial inclusion that are not becoming a primary concerns by some previous studies. Thus, the governments in ASEAN region can propose the financial inclusion policies under high quality of institutions both at country and ASEAN levels. Second, there are three dynamic panel models to estimate the effect of institutions on financial inclusion indicators. Finally, this study practices about 88 observations cover eight countries and eleven series (year).

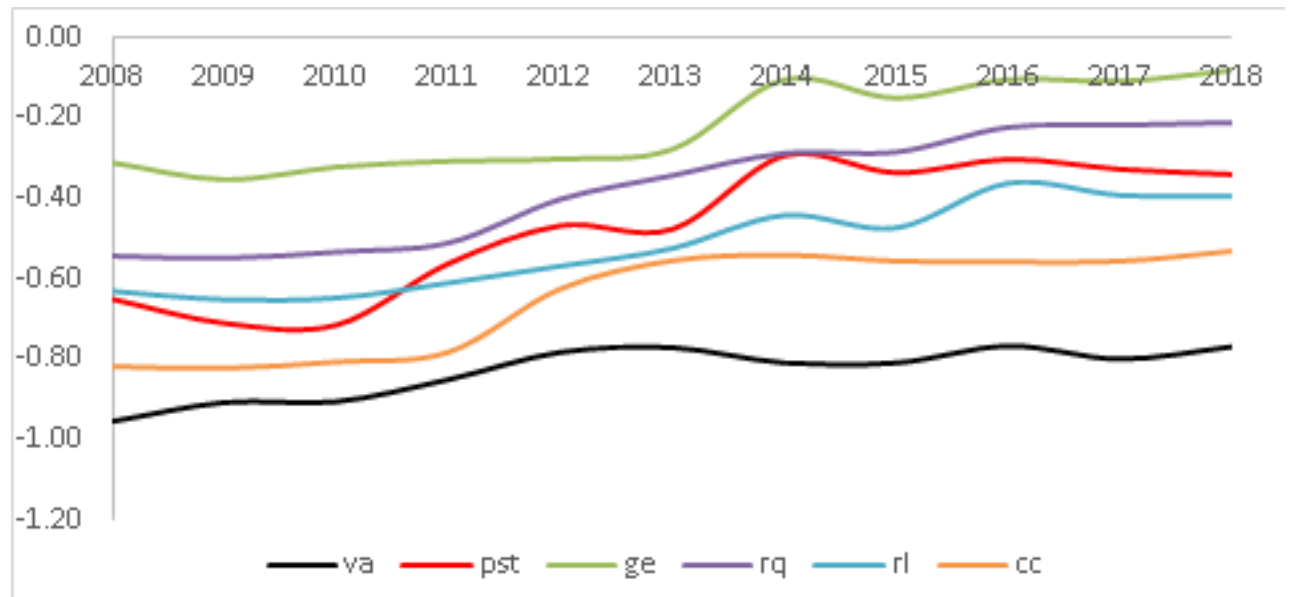

Source: The World Bank (processed)

Note: VA is Voice and accountability, PST is political stability and absence of violence, GE is government effectiveness, RQ is regulatory quality, RL is rule of law, and CC is control of corruption

Figure 1. The Development of Institutional Indicators in ASEAN 8 during 2008-2018 
The lack of discussion on the relationship between institutions and financial inclusion makes it less diverse in the development of literature. Several papers discuss financial inclusion and institutions such as Abel, Muntandwa \& Roux (2018), Allen, Demirguc-Kunt, Klapper \& Perla (2016), Okello, Ntayi \& Munene (2017), Bongomin, Ntayi, Munene \& Malinga (2018); Dwumfour \& Ntow-Gyamfi (2018); and Nkoa \& Song (2020). Abel, Mutandwa, and Roux (2018) explain that the deepening of financial inclusion in various countries is being carried out through codes of practice by financial institutions, central bank directives, and/or national visions supported by government laws. Moreover, Allen, DemirgucKunt, Klapper, and Perla (2016) enlighten that better financial inclusion is associated with lower costs of opening bank accounts, stronger legal rights, and more stable political conditions. Moreover, financial inclusion can also be determined by institutions and social capital in case of Uganda (Bongomin, Ntayi, Munene, and Malinga, 2018). The high level of institutions and social capital leads the high level of financial inclusion. Particularly, the customers of financial sector in rural Uganda depend on the rule of law to be more inclusive in financial transactions. Finally, Dwumfour \& Ntow-Gyamfi (2018) found that quality of institutions can promote financial development in some African countries.

\section{Research Method}

This study uses three financial indicators as a proxy for financial inclusion in ASEAN 8 during 2008-2018. All data were collected from financial index publications and the World Bank. These financial indicators are indicators that are widely utilized in the empirical studies of financial inclusion. Furthermore, there are six institutional indicators were obtained from the World Bank publication under the world governance indicators (WGI). The study will be started from 2008 as a period of the financial crisis. Besides, the eight ASEAN countries are selected as a study sample, namely: Indonesia, Malaysia, Thailand, Cambodia, the Philippines, Vietnam, Lao PDR, and Myanmar. These countries have high effort to improve quality of institutions. During the study period, all countries were still facing low level of institutional quality.

Table 1. Definition of Research Variables

\begin{tabular}{cll}
\hline Variables & \multicolumn{1}{c}{ Definition } & \multicolumn{1}{c}{ Source } \\
\hline DCR & Domestic credit to the private sector (\% of GDP) & The World Bank \\
DCO & Debit card ownership (\% age 15+) & Findex \\
CCO & Credit card ownership (\% age 15+) & Findex
\end{tabular}

Voice and Accountability reflect perceptions of the extent to which a country's citizens can participate in selecting their government, as well as

VA freedom of expression, freedom of association, and free media. An estimate of governance (ranges from approximately -2.5 (weak) to 2.5 (strong) governance performance).

The World Bank

Political Stability and Absence of Violence/Terrorism measures perceptions

PST of the likelihood of political instability and/or politically-motivated violence, including terrorism. An estimate of governance (ranges from approximately -2.5 (weak) to 2.5 (strong) governance performance).

Government Effectiveness reflects perceptions of the quality of public services, the quality of the civil service and the degree of its independence from political

GE pressures, the quality of policy formulation and implementation, and the credibility of the government's commitment to such policies. An estimate of governance (ranges from approximately -2.5 (weak) to 2.5 (strong) governance performance).

Regulatory Quality reflects perceptions of the ability of the government to

RQ formulate and implement sound policies and regulations that permit and promote private sector development. An estimate of governance (ranges from approximately -2.5 (weak) to 2.5 (strong) governance performance). 
Jurnal Ekonomi Pembangunan: Kajian Masalah Ekonomi dan Pembangunan, 21 (2), 2020, 174-186

\begin{tabular}{clc}
\hline Variables & \multicolumn{1}{c}{ Definition } & Source \\
\hline & $\begin{array}{l}\text { Rule of Law reflects perceptions of the extent to which agents have confidence } \\
\text { in and abide by the rules of society, and in particular the quality of contract } \\
\text { RL }\end{array}$ & The World Bank \\
& $\begin{array}{l}\text { likelihood of crime and violence. An estimate of governance (ranges from } \\
\text { approximately -2.5 (weak) to 2.5 (strong) governance performance) }\end{array}$ & \\
& $\begin{array}{l}\text { Control of Corruption reflects perceptions of the extent to which public power is } \\
\text { exercised for private gain, including both petty and grand forms of corruption, }\end{array}$ & The World Bank \\
CC & $\begin{array}{l}\text { as well as "capture" of the state by elites and private interests. An estimate of } \\
\text { governance (ranges from approximately -2.5 (weak) to 2.5 (strong) governance } \\
\text { performance). }\end{array}$ & \\
\hline
\end{tabular}

Table 1 illustrates the definition of study variables. The dependent variable consists of debit card ownership (DCO), credit card ownership (CC), and domestic credit to GDP ratio (DCR). Moreover, the independent variable includes six institutional indicators, namely: voice and accountability (VA), political stability and absence of violence (PST), government effectiveness (GE), regulatory quality (RQ), rule of law (RL), and control of corruption (CC).

This study examines the effect of institutions on financial inclusion in ASEAN 8. Three dynamic panel models will be estimated. The panel model is categoried as the short panel category because the panel period is only 11 years. The basic modeling of dynamic panel has been introduced by Pesaran (2015) that the dependent variable is determined by the lagged of the dependent variable and some explanatoty variables.

The first dynamic panel model will estimate the effect of institutions on dynamic debit card ownership (DCO). Institutional indicators include voice and accountability (VA), political stability and absence of violence (PST), government effectiveness (GE), regulatory quality (RQ), rule of law (RL), and control of corruption (CC). Some previous studies have only concerned on some institutional indicators. In constrast, this study utilized all indicators of institutions under the world governance indicators (WGI). Thus, the dynamic panel model of debit card ownership is as follows:

$\mathrm{DCO}_{\mathrm{it}}=\theta_{0}+\phi_{1} \mathrm{DCO}_{\mathrm{it}-1}+\phi_{2} \mathrm{VA}_{\mathrm{it}}+\phi_{3} \mathrm{PST}_{\mathrm{it}}+$ $\phi_{4} \mathrm{GE}_{\mathrm{it}}+\phi_{5} \mathrm{RQ}_{\mathrm{it}}+\phi_{6} \mathrm{RL}_{\mathrm{it}+} \phi_{7} \mathrm{CC}_{\mathrm{it}+} \varepsilon_{\mathrm{it}}$
Equation (1a) is a Pooled OLS or Common Effects Model (CEM). It can be formulated into Fixed Effects Model (FEM) and Random Effects Model (REM). FEM is also called the Least-Squares Dummy Variable (LSDV) model. Moreover, FEM equation adds the D (dummy) variable in the model that describes the intercept differences (see Equation 1b). Meanwhile, REM assumes that parameters are random. We can add $\varepsilon$ as a random error so that the error term of REM is $w$, where $w=\varepsilon+u$ (see Equation 1c).

$$
\begin{aligned}
& \mathrm{DCO}_{\mathrm{it}}=\theta_{0+} \theta_{1} \mathrm{D}_{\mathrm{ni}}+\phi_{1} \mathrm{DCO}_{\mathrm{it}-1}+\phi_{2} \mathrm{VA}_{\mathrm{it}}+\phi_{3} \mathrm{PST}_{\mathrm{it}}+ \\
& \phi_{4} \mathrm{GE}_{\mathrm{it}}+\phi_{5} \mathrm{RQ}_{\mathrm{it}}+\phi_{6} \mathrm{RL}_{\mathrm{it}+} \phi_{7} \mathrm{CC}_{\mathrm{it}+} \varepsilon_{\mathrm{it}} \\
& \mathrm{DCO}_{\mathrm{it}}=\theta_{0}+\phi_{1} \mathrm{DCO}_{\mathrm{it}-1}+\phi_{2} \mathrm{VA}_{\mathrm{it}}+\phi_{3} \mathrm{PST}_{\mathrm{it}}+\phi_{4} \mathrm{GE}_{\mathrm{it}} \\
& +\phi_{5} \mathrm{RQ}_{\mathrm{it}}+\phi_{6} \mathrm{RL}_{\mathrm{it}+} \phi_{7} \mathrm{CC}_{\mathrm{it}}+\mathrm{w}_{\mathrm{it}}
\end{aligned}
$$

The $\theta_{0}$ is the intercept while $\phi_{1}, \phi_{2}, \phi_{3}, \phi_{4}, \phi_{5}, \phi_{6}$ and $\phi_{7}$ are the parameters/slope of the equation. The value of $\phi_{1.7}$ are $>0$. Furthermore, the $i$ is the cross-section of ASEAN 8 countries while $t$ is a time series of period 2008-2018.

The second dynamic panel model will estimate the effect of institutions on dynamic credit card ownership (CCO). This model becomes the first robustness test. Simmilarly, there are six institutional indicatos as explanatory variables. Hence, the dynamic panel model of credit card ownership is as follows:

$$
\begin{aligned}
& \mathrm{CCO}_{\mathrm{it}}=\theta_{0}+\phi_{1} \mathrm{CCO}_{\mathrm{it}-1}+\phi_{2} \mathrm{VA}_{\mathrm{it}}+\phi_{3} \mathrm{PST}_{\mathrm{it}}+ \\
& \phi_{4} \mathrm{GE}_{\mathrm{it}}+\phi_{5} \mathrm{RQ}_{\mathrm{it}}+\phi_{6} \mathrm{RL}_{\mathrm{it}+} \phi_{7} \mathrm{CC}_{\mathrm{it}+} \varepsilon_{\mathrm{it}}
\end{aligned}
$$

Equation (2a) is a Pooled OLS or Common Effects Model (CEM). Furthermore, FEM 
Jurnal Ekonomi Pembangunan: Kajian Masalah Ekonomi dan Pembangunan, 21 (2), 2020, 174-186

is explained by Equation (2b) while REM is described by Equation (2c).

$\mathrm{CCO}_{\text {it }}=\theta_{0+} \theta_{1} \mathrm{D}_{\mathrm{ni}}+\phi_{1} \mathrm{CCO}_{\mathrm{it}-1}+\phi_{2} \mathrm{VA}_{\mathrm{it}}+\phi_{3} \mathrm{PST}_{\mathrm{it}}+$

$\phi_{4} \mathrm{GE}_{\mathrm{it}}+\phi_{5} \mathrm{RQ}_{\mathrm{it}}+\phi_{6} \mathrm{RL}_{\mathrm{it}+} \phi_{7} \mathrm{CC}_{\mathrm{it}+} \varepsilon_{\mathrm{it}}$

$\mathrm{CCO}_{\mathrm{it}}=\theta_{0}+\phi_{1} \mathrm{CCO}_{\mathrm{it}-1}+\phi_{2} \mathrm{VA}_{\mathrm{it}}+\phi_{3} \mathrm{PST}_{\mathrm{it}}+\phi_{4} \mathrm{GE}_{\mathrm{it}}+$

$\phi_{5} \mathrm{RQ}_{\mathrm{it}}+\phi_{6} \mathrm{RL}_{\mathrm{it}+} \phi_{7} \mathrm{CC}_{\mathrm{it}}+\mathrm{w}_{\mathrm{it}}$

The $\theta_{0}$ is the intercept while $\phi_{1}, \phi_{2}, \phi_{3}, \phi_{4}, \phi_{5}, \phi_{6}$ and $\phi_{7}$ are the parameters/slope of the equation. The value of $\phi_{1.7}$ are $>0$. Furthermore, the $\mathrm{i}$ is the cross-section of ASEAN 8 countries while $t$ is a time series of period 2008-2018.

Furthermore, the third model of dynamic panel will estimate the effect of institutions on the dynamic domestic credit to GDP ratio (DCR). This model will also be employed as a robustness test. Hence, the dynamic panel model of domestic credit to GDP ratio is as follows:

$\mathrm{DCR}_{\mathrm{it}}=\theta_{0}+\phi_{1} \mathrm{DCR}_{\mathrm{it}-1}+\phi_{2} \mathrm{VA}_{\mathrm{it}}+\phi_{3} \mathrm{PST}_{\mathrm{it}}+$ $\phi_{4} \mathrm{GE}_{\mathrm{it}}+\phi_{5} \mathrm{RQ}_{\mathrm{it}}+\phi_{6} \mathrm{RL}_{\mathrm{it}+} \phi_{7} \mathrm{CC}_{\mathrm{it}+} \varepsilon_{\mathrm{it}}$

Equation (3a) is a Pooled OLS or Common Effects Model (CEM). Moreover, FEM is explained by Equation (3b) while REM is described by Equation (3c).

$\mathrm{DCR}_{\mathrm{it}}=\theta_{0+} \theta_{1} \mathrm{D}_{\mathrm{ni}}+\phi_{1} \mathrm{DCR}_{\mathrm{it}-1}+\phi_{2} \mathrm{VA}_{\mathrm{it}}+\phi_{3} \mathrm{PST}_{\mathrm{it}}+$ $\phi_{4} \mathrm{GE}_{\mathrm{it}}+\phi_{5} \mathrm{RQ}_{\mathrm{it}}+\phi_{6} \mathrm{RL}_{\mathrm{it}+} \phi_{7} \mathrm{CC}_{\mathrm{it}+} \varepsilon_{\mathrm{it}}$ $\mathrm{DCR}_{\mathrm{it}}=\theta_{0}+\phi_{1} \mathrm{DCR}_{\mathrm{it}-1}+\phi_{2} \mathrm{VA}_{\mathrm{it}}+\phi_{3} \mathrm{PST}_{\mathrm{it}}+\phi_{4} \mathrm{GE}_{\mathrm{itt}}+$ $\phi_{5} \mathrm{RQ}_{\mathrm{it}}+\phi_{6} \mathrm{RL}_{\mathrm{it}+} \phi_{7} \mathrm{CC}_{\mathrm{it}}+\mathrm{w}_{\mathrm{it}}$

The $\theta_{0}$ is the intercept while $\phi_{1}, \phi_{2}, \phi_{3}, \phi_{4,}, \phi_{5}, \phi_{6}$ and $\phi_{7}$ are the parameters/slope of the equation. The value of $\phi_{1-7}$ are $>0$. Furthermore, the $\mathrm{i}$ is the cross-section of ASEAN 8 countries while $t$ is a time series of period 2008-2018.

\section{Results and Discussion}

\subsection{Results and Robustness Checks}

ASEAN Countries have strong initiatives in expanding access and deepening financial transactions. It is also used to support the implementation of the ASEAN economic community (AEC). In contrast, some ASEAN countries still face institutional problems and inequality of financial access for all people in the region. Thus, an empirical study to estimate the effect of institutitons on financial inclusion is needed.

This study employs three indicators of financial inclusion, namely: debit card ownership (DCO), credit card ownership (CCO), and domestic credit to GDP ratio (DCR). Some explanatory variables were selected covering voice and accountability (VA), political stability and absence of violence (PST), government effectiveness (GE), regulatory quality (RQ), rule of law (RL) and control of corruption (CC).

Table 2 shows descriptive statistics results on indicators of financial inclusion and institutions in ASEAN 8 during 2008-2018. During the study period DCO, CCO and DCR have an average value (mean) about 547.16\%, 119.73\%, and $64.71 \%$, respectively. It describes financial transactions in the ASEAN region are relatively increasing. In addition, debit card ownership tends to be higher compared to credit card ownership. Indeed, in the ASEAN region households make financial transaction under income in cash. The governments can also stimulate domestic credit especially for supporting business activities.

Table 2. Descriptive Statistics

\begin{tabular}{lllrrr}
\hline Variable & & Mean & Std. Dev. & \multicolumn{1}{c}{ Min } & \multicolumn{1}{c}{ Max } \\
\hline dco & overall & 547.155 & 541.562 & 0.699 & 1887.982 \\
& Between & & 556.033 & 3.706 & 1627.299 \\
& Within & & 140.193 & 193.448 & 847.058 \\
cco & overall & \multirow{2}{*}{119.732} & 147.408 & 0.001 & 431.101 \\
& between & & 155.455 & 0.373 & 398.484 \\
& within & & 18.459 & 60.828 & 187.750 \\
dcr & overall & 64.707 & 46.492 & 3.121 & 149.373 \\
\hline
\end{tabular}


Avalaible online at http://journals.ums.ac.id, Permalink/DOI: 10.23917/jep.v21i2.11146

Jurnal Ekonomi Pembangunan: Kajian Masalah Ekonomi dan Pembangunan, 21 (2), 2020, 174-186

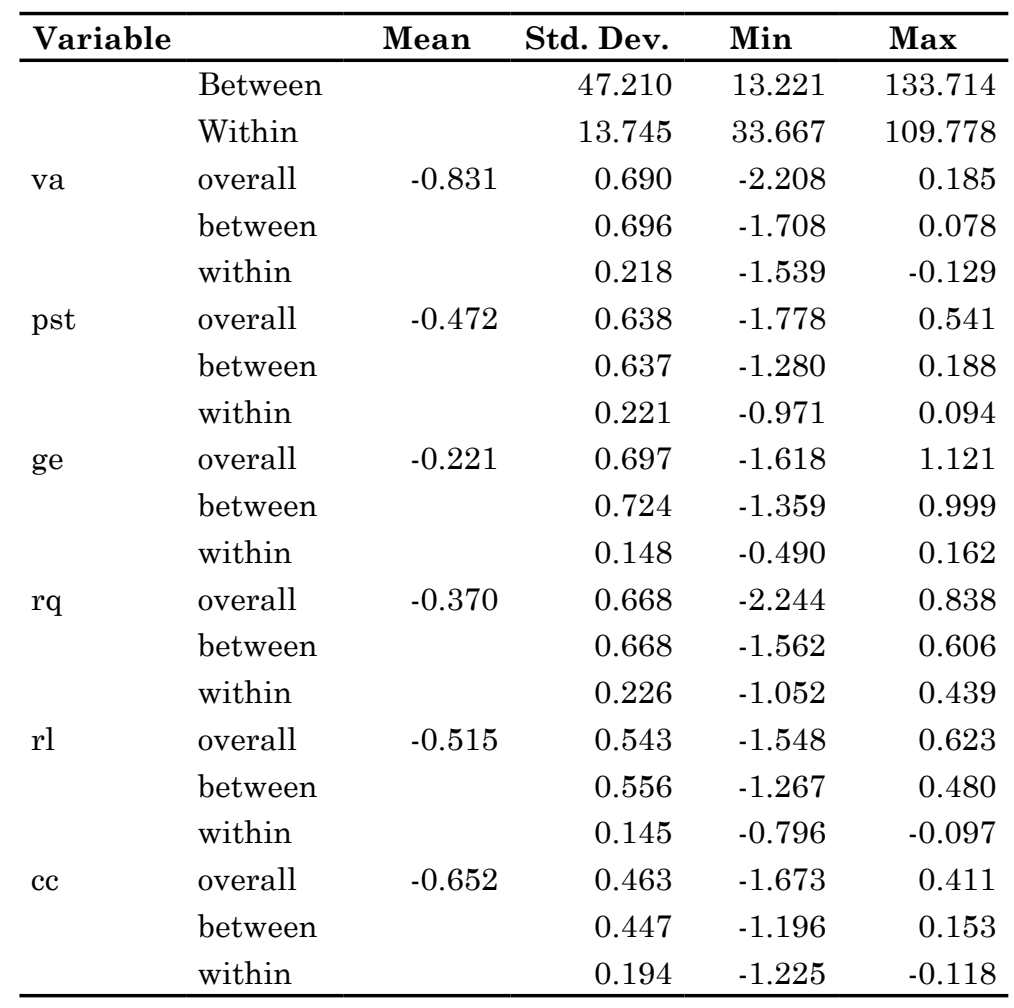

Source: Secondary data (processed)

In general, the mean value of institutional indicators are negative (-). It means that the institutional level in the region is relatively low. Furthermore, the low quality institutions becomes a restriction for financial inclusion acceleration. Thus, this study concerns on the issue and address the empirical gaps on the linkage between institutions and financial inclusion in ASEAN countries. Hence, the higher level of institutions will lead the higher level of financial inclusion.

The Equation (1a), (1b) and (1c) will be estimated using dynamic panel data. The results are expressed by Table 3 . The dependent variable is debit card ownership (DCO). There are three panel model employed such as Pooled OLS, fixed effects model and random effects model. Fixed effects model (FEM) is an appropriate empirical model under Hausman test.

The findings explain that debit card ownership (DCO) is determined by the lagged of DCO and some indicators of institutions. It exhibits that dynamic panel of financial inclusion under debit card ownership occurs. There are two indicators of institutions, namely: voice and accountability (VA) and rule of law (RL). Besides, the constant of the equation also has a significant effect.

The higher voice and accountability will lead the lower financial inclusion. This finding informs that the openness and accountability of economic and financial transactions were still low and need to be improved. The governments in ASEAN region should promote openness and accountability in economic and financial polices in order to promote financial inclusion. Thus, the linkage of voice and accountability on financial inclusion should be a positive. In constrast, the higher rule of law leads the higher level of financial inclusion. Simply words, law enforcement in the financial sector has significant implications for the public to utilize debit card in financial transaction. Besides, the public also puts a high confidence to save their money in financial institutions.

The R-square of FEM is about 0.4565 (within the group). It informs that about $45.65 \%$ of the dependent variable is determined by variations 
of the independent variables. Furthermore, the $\mathrm{R}$-square of cross-sectional estimation is about $65.30 \%$ (between the group). R-square of overall estimation is about $63.65 \%$. Finally, the value of F-statistics is significant at $1 \%$ of significant level. Thus, the FEM model can express the linkage between insitutions and debit card ownership in selected ASEAN countries during the study periods.

Equation (2a), (2b) and (2c) will be estimated using dynamic panel data that reflect dynamic credit card ownership (CCO). There are some explanatory variables such as lagged of $\mathrm{CCO}$, voice of accountability (VA), political stability and absence of violence (PST), government effectiveness (GE), regulatory quality (RQ), rule of law (RL) and control of corruptiom (CC). Besides, three models of panel data will be employed such as Pooled OLS, fixed effects and random effects model (Table 4).

The findings describe fixed effects model (FEM) is a precise empirical model under Hausman test. Moreover, the dynamic financial inclusion occurs because the credit card ownership (CCO) is determined by the lagged of CCO. It means that the higher level of $\mathrm{CCO}$ in the current period was effected by the higher level of $\mathrm{CCO}$ in the previous period. Likewise, there are some institutional indicators have significant impact on financial inclusion such as voice and accountability (VA) and rule of law (RL). In addition, the constant of the equation also has a significant impact on CCO.

VA and RL have implication on financial inclusion both under credit card ownership and debit card ownership. The findings clarify that the dynamic financial inclusion under debit card ownership and credit card ownership are robust. Thus, the governments in ASEAN countries should concern on the quality of accountability in financial policies and improve the quality of law enforcement. The governments can promote the quality of institutions both in country and ASEAN levels.

Table 3. Financial Inclusion under Dynamic Debit Card Ownership

\begin{tabular}{|c|c|c|c|}
\hline Variable & Pooled OLS & Fixed Effects & Random Effects \\
\hline $\operatorname{DCO}(-1)$ & $0.3867 \quad(0.3173) \quad[1.22]$ & $0.3846(0.2240)[1.72]^{*}$ & $0.3867(0.3173) \quad[1.22]$ \\
\hline VA & $9.9461(50.9506) \quad[0.20]$ & $-350.3544(122.3795)[2.86]^{* *}$ & $9.9461(50.9506) \quad[0.20]$ \\
\hline PST & $-26.8521(38.1033)[-0.70]$ & $-86.1415(80.4702)[1.07]$ & $-26.8521(38.1033) \quad[-0.70]$ \\
\hline GE & $62.2036(136.6291)[0.46]$ & $-177.5853(145.9582)$ [1.22] & $62.2036(136.6291)[0.46]$ \\
\hline $\mathrm{RQ}$ & $-237.4555(87.5630)[-2.71]^{* *}$ & $25.2108(137.8662)$ [0.18] & $-237.4555(87.5630)[-2.71]^{* *}$ \\
\hline $\mathrm{RL}$ & $1029.211(180.1589)[5.71]^{* * *}$ & $703.9885(136.9310)[5.14]^{* * *}$ & $1029.211(180.1589)[5.71]^{* * * *}$ \\
\hline $\mathrm{CC}$ & $126.5462(121.0237)$ [1.05] & $231.8760 \quad(156.4510)$ [1.48] & $126.5462 \quad(121.0237) \quad[1.05]$ \\
\hline Constant & $1073.936(74.7433)[14.37]^{* * *}$ & $697.0730(90.3354)[7.72]^{* * *}$ & $1073.936(74.7433)[14.37]^{* * *}$ \\
\hline \multicolumn{4}{|l|}{$\mathrm{R}$-square: } \\
\hline Within & & 0.4565 & 0.3640 \\
\hline Between & & 0.6530 & 0.9678 \\
\hline Overall & 0.9113 & 0.6365 & 0.9192 \\
\hline \multicolumn{4}{|l|}{$\begin{array}{l}\text { Wald Chi- } \\
\text { square }\end{array}$} \\
\hline (F-statistics) & $116.99^{* * *}$ & $7.80^{* * *}$ & $818.93^{* * *}$ \\
\hline LM Test & 0.00 & & \\
\hline Hausman Test & & $29.13^{* * *}$ & \\
\hline Observations & 88 & 88 & 88 \\
\hline
\end{tabular}

Source: Research output

Note: () is Standard Error

[ ] is Z-statictics

$* * *, * *$ and $*$ denote significant levels at $1 \%, 5 \%$ and $10 \%$, respectively 
Avalaible online at http://journals.ums.ac.id, Permalink/DOI: 10.23917/jep.v21i2.11146

Jurnal Ekonomi Pembangunan: Kajian Masalah Ekonomi dan Pembangunan, 21 (2), 2020, 174-186

Table 4. Financial Inclusion under Dynamic Credit Card Ownership

\begin{tabular}{|c|c|c|c|c|}
\hline Variable & Pooled OLS & Fixed Effects & Ra & ndom Effects \\
\hline $\operatorname{CCO}(-1)$ & $0.4081(0.7014)[0.58]$ & $0.79108(0.1815)[4.36]^{* * *}$ & 0.408 & $1(0.7014)[0.58]$ \\
\hline VA & $-85.6046(17.9837)[-4.76]^{* * *}$ & $-56.9280(15.2588)[3.73]^{* * *}$ & -85.6046 & $(17.9838)[4.76]^{* * *}$ \\
\hline PST & $-99.8829(13.5217)[-7.39]^{* * *}$ & $-9.0717(10.1239)[0.90]$ & -99.8829 & $(13.5217)[7.39]^{* * *}$ \\
\hline GE & $53.9657(48.8008)[1.11]$ & $10.8491(18.2157)[0.60]$ & 53.965 & $7(48.8008)[1.11]$ \\
\hline RQ & $92.7377(30.9757)[2.99]^{* *}$ & $21.9514(16.7357) \quad[1.31]$ & 92.7377 & $(30.9757)[2.99]^{* *}$ \\
\hline RL & $165.9182(64.9371)[2.56]^{* *}$ & $65.4751(17.0031)[3.85]^{* * *}$ & 165.9182 & $(64.9371)[2.56]^{* *}$ \\
\hline $\mathrm{CC}$ & $-23.8785(42.2661) \quad[-0.56]$ & $-16.2598(19.3187)[0.84]$ & -23.878 & $5(42.2661) \quad[0.56]$ \\
\hline Constant & $116.6464(25.2599)[4.62]^{* * *}$ & $100.4244(11.0380)[9.10]^{* * *}$ & 116.6464 & $(25.2599)[4.62] * * *$ \\
\hline R-square: & & & & \\
\hline Within & & 0.5415 & & 0.1490 \\
\hline Between & & 0.4403 & & 0.8987 \\
\hline Overall & 0.8493 & 0.4263 & & 0.8627 \\
\hline $\begin{array}{l}\text { Wald Chi- } \\
\text { square }\end{array}$ & & & & \\
\hline (F-statistics) & $64.62^{* * *}$ & $10.97^{* * *}$ & & $452.34^{* * *}$ \\
\hline LM Test & & 0.00 & & \\
\hline Hausman Test & & \multicolumn{3}{|c|}{$403.52^{* * *}$} \\
\hline Observations & 88 & 88 & & 88 \\
\hline
\end{tabular}

Source: Research output

Note: () is Standard Error

[ ] is Z-statictics

$* * *, * *$ and $*$ denote significant levels at $1 \%, 5 \%$ and $10 \%$, respectively

Table 5. Financial Inclusion under Dynamic Domestic Credit to GDP Ratio

\begin{tabular}{|c|c|c|c|}
\hline Variable & Pooled OLS & Fixed Effects & Random Effects \\
\hline $\operatorname{DCR}(-1)$ & $1.6064(0.4693)[3.42]^{* * *}$ & $0.8179(0.2194)[3.73]^{* * *}$ & $1.6064(0.4693)[3.42]^{* * *}$ \\
\hline VA & $-52.1818(6.9163)[-7.54]^{* * *}$ & $-21.7616(10.8353)[2.01]^{* *}$ & $-52.1818(6.9163)[7.54]^{* * *}$ \\
\hline PST & $-21.2355(5.1547)[-4.12]^{* * *}$ & $19.5168(6.9668)[2.80]^{* *}$ & $-21.2355(5.1547)[4.12]^{* * *}$ \\
\hline GE & $-3.1964(18.6565)[-0.17]$ & $7.3189(12.7148)[0.58]$ & $-3.1964(18.6565)[0.17]$ \\
\hline RQ & $52.7676(12.0586)[4.38]^{* * *}$ & $46.6181(12.0673)[3.86]^{* * *}$ & $52.7676(12.0586)[4.38]^{* * *}$ \\
\hline $\mathrm{RL}$ & $59.3238(24.4375)[2.43]^{* *}$ & $17.3779(11.9957)[1.45]$ & $59.3238(24.4375)[2.43]^{* *}$ \\
\hline $\mathrm{CC}$ & $-10.1602(16.2958)[-0.62]$ & $-37.0319(13.4811)[2.75]^{* *}$ & $-10.1602(16.296)[0.62]$ \\
\hline Constant & $50.0803(9.8781)[5.07]^{* * *}$ & $58.0067(7.9922)[7.26]^{* * *}$ & $50.0803(9.8781)[5.07] * * *$ \\
\hline \multicolumn{4}{|l|}{ R-square: } \\
\hline Within & & 0.5391 & 0.2998 \\
\hline Between & & 0.4790 & 0.8521 \\
\hline Overall & 0.7743 & 0.4834 & 0.7943 \\
\hline \multicolumn{4}{|l|}{ Wald Chi-square } \\
\hline (F-statistics) & $39.72^{* * *}$ & $10.86^{* * *}$ & $278.05^{* * *}$ \\
\hline LM Test & & 0.00 & \\
\hline Hausman Test & & \multicolumn{2}{|c|}{$152.84^{* * *}$} \\
\hline Observations & 88 & 88 & 88 \\
\hline
\end{tabular}

Source: Research output

Note: () is Standard Error

[ ] is Z-statictics

$* * * * * *$ and * denote significant levels at $1 \%, 5 \%$ and $10 \%$, respectively 
The R-square of FEM is about 0.5415 (within the group). It means that about $54.15 \%$ of the dependent variable is determined by variations in the independent variables. Moreover, the $\mathrm{R}$-square of cross-sectional estimation is about $44.03 \%$ (between the group). R-square of overall estimation is about $42.63 \%$. Hence, the value of F-statistics is significant. It exhibit that the explanatory variables can determine credit card ownership simultanously.

The Equation (3a), (3b) and (3c) will be estimated using dynamic panel data under domestic credit to GDP ratio (DCR). Some explanatory variables were selected such as lagged of DCR and six indicators of institutions. Besides, the equations become robustness checking.

The findings explain that dynamic financial inclusion under domestic credit to GDP ratio occurs (Table 5). It means that domestic credit to GDP ratio (DCR) is significantly effected by the lagged of DCR. Furthermore, there four institutional indicators significantly determine financial inclusion, namely: voice and accountability (VA), political stability and absence of violence (PST), regulatory quality (RQ), and control of corruption (CC).

The higher level of voice and accountability will lead the lower level of financial inclusion. Similarly, the higher level of control of corruption lead the lower of financial inclusion. The findings express that the governments in ASEAN region still face risks of accountability and corruptive practices. Indeed, the governments have encouraged all economic agents (including governments agencies) to reform the low level of governance and stimulate anti-corruption body.

Moreover, the higher level of two indicators of institutions will promote financial inclusion in ASEAN countries. The indicators consist of political stability and absence of violence and regulatory quality. The findings send a positive sinyal to the financial inclusion that the governments can assurance the stability of politics and law enforcement. Thus, the governments should keep sustainability of high level of political stability and requlatory quality both in country and ASEAN levels.

The R-square of FEM is about 0.5391 (within the group). It means that about $53.91 \%$ of the dependent variable is determined by variations in the independent variables. Besides, the $\mathrm{R}$-square of cross-sectional estimation is about $47.90 \%$ (between the group). R-square of overall estimation is about $48.34 \%$. Furthermore, the value of $\mathrm{F}$-statistics is significant. It reflects the significant of all explanatory variables on financial inclusion simultanously.

\subsection{Discussion}

This study attempts to estimate the linkage between institutions and financial inclusion indicators in selected ASEAN countries during 2008-2018. Dynamic panel model was employed to examine the Equation (1a) - (3c). There are three indicators of financial inclusion, namely: debit card ownership (DCO), credit card ownership (CCO), and domestic credit to GDP ratio (DCR). Furthermore, the study was selected six indicators of institutions published by the World Bank in world governance indicators (WGI), namely: voice and accountability (VA), political stability and absence of violence (PST), government effectiveness (GE), regulatory quality (RQ), rule of law (RL), and control of corruption (CC). Besides, the eight ASEAN countries become a study sample because the countries were still facing low level of institutions and trying to improve high level of financial inclusion.

Previous studies conducted by Bongomin, Ntayi \& Munene (2016) and Okello, Munene, Ntayi, and Akol (2017) found that the institutional framework have significant impact on financial inclusion in rural Uganda. The institutional framework is not only formal but also informal. Furthermore, Allen, Demirguc-Kunt, Klapper, and Perla (2016) identified several indicators of implementing financial inclusion, namely: financial transaction costs, closeness to financial intermediaries, stronger legal rights, and stable politics. Some explanatory variables can determine 
Jurnal Ekonomi Pembangunan: Kajian Masalah Ekonomi dan Pembangunan, 21 (2), 2020, 174-186

financial inclusion such as demographics and socioeconomic (for example gender, age, rural residence, income, education, marital status) and finance (for example the cost of opening a bank account, maintaining, and using a bank account). They suggest that the government has an important role to promote financial inclusion and increase individual confidence in the financial transaction.

This study found that dynamic financial inclusion occurs in selected ASEAN countries during the study period. It can be expressed by the significant impact of lagged of financial inclusion indicators in the Table 3-5. In general, four indicators of institutions significantly effect on domestic credit to GDP ratio. In contrast, there are two indicators of institutions significantly impact on debit card ownership and credit card ownership. Voice and accountability hits three indicators of financial inclusion such as debit card ownership, credit card ownership, and domestic credit to GDP ratio. Furthemore, control of corruption also harm domestic credit to GDP ratio. The findings indicates the goverments in ASEAN region still face problem to stimulate transparency, accountability and anti-corruption practices.

The findings also express the significant role of political stability and rule of law on debit card ownership and credit card ownership. These indicators of institutions can promote high level of financial inclusion indicators. Meanwhile, domestic credit to GDP ratio was determined by political stability and regulatory quality. Similarly, these indicators also lead high level of financial inclusion indicators in selected ASEAN countries. Moreover, the results of this study are relevant to previous empirical studies that political stability and rule of law can encourage financial inclusion improvement. Therefore, the governments in the ASEAN region can collaborate to promote inclusiveness of financial transactions and increase the level of institutional quality both at country and ASEAN levels.

Some previous studies found that institutions has significant contribution on financial inclusion in various ways such as Zins \& Weill (2016), Okello, Ntayi \& Munene (2017), Hartwell (2017), Leroy \& Pop (2018), and Williams (2018). Zins \& Weill (2016) report some African countries still face low level of financial inclusion. Therefore, the goverments and banking industries should create a specific targets such as women and young people to accelate financial inclusion in African countries. Moreover, Okello, Ntayi, and Munene (2017) explain that it is not only institutions but also financial literacy. Institutional quality improvement will be responded by financial inclusion through financial literacy. The governments is advised not only to improve financial inclusion but to improve the quality of institutions and financial literacy simultanously. This is addressed to reduce the transaction gap and financial literacy between cities and villages, between low and high-income people. Hartwell (2017) adds some indicators of institutions such as property right and democracy can encourage the financial volatility in Central and Eastern Europe and the former Soviet Union. The democracy indicator was also utilized by Williams (2018) to examine the linkage between credit market and economic growth in emerging and developing economies. In contrast, Leroy \& Pop (2018) argue that the specific mix of institutional arrangements do not significantly contribute in forming the macro-financial linkages.

Bongomin, Ntayi, Munene \& Malinga (2018) utilize social capital as a medium of institutional impactonfinancialinclusion in Uganda. The higher level of quality of institutions has implications for increasing social capital. Moreover, an increase in social capital can encourage financial inclusion improvement. Therefore, the government can facilitae and support social capital practices, especially in rural communities in the case of increasing and expanding financial inclusion.

There are two institutional indicators negatively impact on financial inclusion in selected ASEAN countries, namely: voice and accountability, and control of corruption. It indicates the quality of institutions cannot encourage financial inclusion properly. It can 
Jurnal Ekonomi Pembangunan: Kajian Masalah Ekonomi dan Pembangunan, 21 (2), 2020, 174-186

be assumed that the ability of governments in the ASEAN region to realize accountability, transparency, and control corruption in financial transactions has not been maximally implemented yet. Therefore, governments in selected ASEAN countries should collaborate to improve the quality of institutions for boosting financial inclusion both in country and ASEAN levels.

\section{Conclusions}

Some ASEAN countries were still facing problem on financial inclusion and quality of institutions. In general, the level of institutions in all countries were low. The previous empirical studies have found that there is a significant contribution of institutions on financial inclusion. Thus, this study aims to estimate the linkage between institutions and financial inclusion in selected ASEAN countries during 2008-2018. The dynamic panel model was employed to examine the Equation (1a) - (3c). Furthermore, three financial inclusion indicators and six indicators of institutions were selected in dynamic panel models. Our main findings can be summarized as follows.

The main findings exhibit the significant impact of some institutional indicators on financial inclusion indicators. For example, voice and accountability (VA) and the rule of law (RL) have a significant impact on dynamic debit card ownership and credit card ownership. The VA has a negative impact while the RL has a positive impact. Furthermore, there are four indicators of institutions significantly contribute to dynamic domestic credit to GDP ratio such as VA, PST, RQ (regulatory quality), and CC (control of corruption). Thus, the dynamic panel models of financial inclusion indicators are robust.

The study imply and provide some policy recommendatio to governments in ASEAN such as improve quality of institutions. Transparent, integrated, and accountable financial sector policies can be supported by control corruption and domestic political stability. Likewise, business actors and the public are expected becoming primary economic agents to realize financial inclusion in the region. Hence, cashless transactions and institutional reform can be the main objective of financial sector policies in ASEAN countries.

\section{References}

Abel,S.,Mutandwa,L.,\&Roux,P.L.(2018).AReview of Determinants of Financial Inclusion. International Journal of Economics and Financial Issues, Econjournals, 8(3), 1-8. RePEc:eco:journ1:2018-03-1

Akudugu, M. A. (2013). The determinants of financial inclusion in Western Africa: Insights from Ghana. Research Journal of Finance and Accounting, 4 (8), 1-10. https://www.researchgate.net/ publication $/ 254258038$

Akudugu, M. A., Egyir, I. S. \& Akwasi, M.B. (2009). Women farmers' access to credit from rural banks in Ghana. Agricultural Finance Review, 69(3), 284-299. RePEc:eme:afrpps:v:69:y:2009:i:3:p:284-299

Allen, F., Demirguc-Kunt, A., Klapper, L. \& Perla, M. S. M. (2016). The foundations of financial inclusion: Understanding ownership and use of formal accounts. Journal of Financial Intermediation, 27, 1-30. http:// www.sciencedirect.com/science/article/pii/ S1042957315000534

Anarfo, E. B., Abor, J. Y., \& Osei, K. A. (2019). Financial Regulation and Financial Inclusion in Sub-Saharan Africa: Does Financial Stability Play a Moderating Role? Research in International Business and Finance, 51, 101070. Doi:10.1016/j. ribaf.2019.101070

Arun, T., \& Kamath, R. (2015). Financial inclusion: Policies and practices. IIMB Management Review, 27(4), 267-287. Doi:10.1016/j. iimb.2015.09.004

Bongomin, G. O. C., Ntayi, J. M. \& Munene, J. (2016). Institutional frames for financial inclusion of poor households in SubSaharan Africa. International Journal of Social Economics, 43 (11), 1096-1114. 
http://dx.doi.org/10.1108/IJSE-06-20140110

Bongomin, G. O. C., Ntayi, J. M., Munene, J. C. M. \& Malinga, C. A. (2018). Institutions and financial inclusion in Rural Uganda: the mediating role of social capital. Journal of African Business, 19(2), 244-261. https:// doi.org/10.1080/15228916.2018.1425961

Burlando, A., \& Canidio, A. (2017). Does group inclusion hurt financial inclusion? Evidence from ultra-poor members of Ugandan savings groups. Journal of Development Economics, 128, 24-48. Doi:10.1016/j. jdeveco.2017.05.001

Christen, R.P, \& Pearce, D. (2005). Managing risks and designing products for agricultural microfinance: features of an emerging model. CGAP Occasional Paper No. 11, 1-51. Available at: https://www.cgap.org

Datta, D. S. K., \& Singh, D. K. (2019). Variation and Determinants of Financial Inclusion and association with Human Development: A Cross Country Analysis. IIMB Management Review, 1-30. doi:10.1016/j. iimb.2019.07.013

Dwumfour, R. A., \& Ntow-Gyamfi, M. (2018). Natural resources, financial development and institutional quality in Africa: Is there a resource curse? Resources Policy, 59, 411426. Doi:10.1016/j.resourpol.2018.08.012

Ghosh, S., \& Vinod, D. (2017). What Constrains Financial Inclusion for Women? Evidence from Indian Micro data. World Development, 92, 60-81. Doi:10.1016/j. worlddev.2016.11.011

Hartwell, C. A. (2017). The impact of institutional volatility on financial volatility in transition economies. Journal of Comparative Economics, 46(2), 598-615. Doi:10.1016/j. jce.2017.11.002

Khan, M. A., Gu, L., Khan, M. A., \& Oláh, J. (2020). Natural Resources and Financial Development: The Role of Institutional Quality. Journal of Multinational Financial Management, 100641. Doi:10.1016/j. mulfin.2020.100641
Loo, M. K. L. (2019). Enhancing financial inclusion in ASEAN: Identifying the best growth markets for fintech. Journal of Risk and Financial Management, 12(4), 1-21. https://doi.org/10.3390/jrfm12040181

Leroy, A., \& Pop, A. (2018). Macro-financial linkages: The role of the institutional framework. Journal of International Money and Finance, 1-45. Doi:10.1016/j. jimonfin.2018.12.002

Nkoa, B. E. O., \& Song, J. S. (2020). Does institutional quality affect financial inclusion in Africa? A panel data analysis. Economic Systems, 100836. Doi:10.1016/j. ecosys.2020.100836

Okello, G. C. B., Munene, J. C., Ntayi, J. M. \& Akol, C. M. (2017). Analyzing the relationship between institutional frameworks and financial inclusion in rural Uganda: A social network perspective. International Journal of Emerging Markets, 1-23. https:// doi.org/10.1108/IJoEM-02-2017-0057

Pesaran, M. H. (2015). Time Series and Panel Data Econometrics. UK: Oxford University Press.

Sarma, M. (2016). Measuring Financial Inclusion for Asian Economies. In Gopalan, S. \& Kikuchi, T. (2016, Editor). Financial Inclusion in Asia: Issues and Policy Concerns. London: Palgrave Macmillan.

Williams, K. (2018). Do political institutions improve the diminishing effect of financial deepening on growth? Evidence from developing countries. Journal of Economics and Business, 1-15. doi:10.1016/j. jeconbus.2018.11.003

$\mathrm{Xu}, \mathrm{X}$. (2019). Trust and Financial Inclusion: A Cross-country Study. Finance Research Letters, 101310. Doi:10.1016/j. frl.2019.101310

Zins, A., \& Weill, L. (2016). The determinants of financial inclusion in Africa. Review of Development Finance, 6(1), 46-57. doi:10.1016/j.rdf.2016.05.001 